\title{
EVALUATION OF ENVIRONMENTAL HAZARD DURING SHALE GAS EXPLORATION PROCESS IN POLAND IN THE YEARS 2012-2014
}

\author{
OCENA ZAGROŻENIA ŚRODOWISKA PODCZAS POSZUKIWAŃ GAZU \\ ŁUPKOWEGO W POLSCE W LATACH 2012-2014
}

\begin{abstract}
This paper is a summary of results of environmental analysis conducted by PGI-NRI, AGH-UST within the monitoring of natural gas prospecting in unconventional deposits. All elements of natural environment were analyzed and on this basis the qualitative and quantitative impact of drilling and hydraulic fracturing of shales could be assessed. Special attention was drawn to the analysis of the physicochemical condition of post-reaction fluids, soil gas in the well pad area and drilling fluids. The results of analysis reveal that prospecting works do not create a significant environmental hazard. Some indices connected, e.g. with the noise climate lightly exceeded permissible values. Nonetheless, if extensive prospecting and production of shale gas are involved, the environmental studies need to be broadened to supplement this report.
\end{abstract}

Keywords: natural gas, unconventional deposits, shale gas, exploration boreholes, environment, groundwater monitoring, noise, hydraulic fracturing, fracturing fluid, spent fracturing fluid, reserve groundwater resources

\section{Introduction}

By the term ,conventional gas”, we usually define ,free gas” trapped in multiple, porous zones in various naturally occurring rock formations such as carbonates, sandstones, and siltstones. "Unconventional gas" is trapped in geologic formations with very low permeability $[1,2]$. Unconventional reservoirs mainly include shale gas, coal bed methane (CBM), and tight gas. Other 'unconventional gas' - hydrate deposits are an additional (largest) unconventional gas resource [3,4]. The first three types of unconventional rocks have different characteristics $[1,5]$ :

1. Shale gas in the clayey mudrocks (shale gas). The basic substance constituting the organic layer generating the gas and oil is kerogen. Gas remains in the bedrock, does not migrate into other layers.

\footnotetext{
${ }^{1}$ Polish Geological Institute - National Research Institute, ul. Rakowiecka 4, 00-975 Warszawa, Poland, phone +482245920 25, fax +482245920 01, email: mkon@pgi.gov.pl

${ }^{2}$ Faculty of Drilling, Oil and Gas, AGH University of Science and Technology in Kraków, al. A. Mickiewicza 30, 30-059 Kraków, Poland, phone +48 1261722 29, fax +48 126340052

*Corresponding author: macuda@agh.edu.pl
} 
2. CBM - gas (methane) in coal beds, both in the free form in the cracks, as well as in the form of adsorbed (above $90 \%$ ).

3. Tight gas - gas in reservoirs with low permeability (from $<1.0 \cdot 10^{-16} \mathrm{~m}^{2}$ to $<1.0 \cdot 10^{-18} \mathrm{~m}^{2}$ ) contained in pores with limited connections between them (no adsorption gas).

The low permeability of shale rocks causes marginal productivity in vertical wells and to increase the capacity of gas from wells the horizontal well drilling with the multistage stimulation process is commonly (after 2007) proposed. During horizontal section drilling, the drill bit is steered from its downward trajectory to follow a horizontal trajectory for 1-2 $\mathrm{km}$ or more to thereby exposing the wellbore to as much reservoir as possible. Artificial fractures provide the permeability for gas to flow, open existing naturally micro fracturing network, but contribute little to the overall gas storage capacity is related to the matrix.

The potential and real hazards of the natural environment and human health have been a subject of heated discussions in USA and Europe for last years, respectively [6-9]. The discussion in the USA started after the presentation of a film „GASLAND” (dir. J. Fox) in 2010, and after series of ecological papers in local newspapers, lectures in the eastern U.S. states, (e.g. Pennsylvania, West Virginia and Ohio) in the years 2008-2013. One of the results of the public discussion, is prohibition of shale gas fracturing in Vermont (2012), Maryland (2015), New York (2015), Washington D.C., within cities of some states (e.g. Colorado, Texas), and some counties of California, New Mexico, Ohio. The other issue relevant to shale gas production is a process of injection of produced waters and wastes into the reservoir. The process is very popular in the Texas (more than 2000 wells), but in several states has been stopped due to the increased number of earthquakes linked with unconventional gas drilling wastes injection (see Arkansas, Massachusetts, New Jersey). Time banning moratoria for fracturing process exist or existed in the various countries (e.g. France, Bulgaria, Luxemburg, The Netherlands) and some regions of Canada (Quebec Province), Spain, and UK (Scotland and Wales).

All possible environmental impacts of the extraction activities have been widely discussed in public media and scientific society. The first partial summary of the discussion can be found in several reports [3, 6, 9-11]. Most of these reports refer to the effect of drilling activity on the environment, not only recognition but also drilling and industrial production. In 2010, gas production from unconventional reservoirs (shale rocks, tight rocks and $\mathrm{CBM}$ ) reached $200 \mathrm{Bcm}$ (billion cubic meters) (which is $28 \%$ of total gas production in the USA in the year) [12-14]. In 2014, the total gas production in the USA achieved $687 \mathrm{Bcm}$, out of which shale gas production exceeded 54\% (see Figs. 1 and 2).

After the publication of the first report of the IEA [15], the discussion became even more vivid as the potential natural gas resources in Europe - indicated by the IEA can partly change the Europe dependence on the natural gas import from Eurasia and North Africa [16]. The discussion about shale gas in Europe were broadened by issues connected with energy safety in EU countries [17-19].

According to the long-term predictions, even $94 \%$ of gas will come from EU and import if no production from new European deposits is obtained. At least half of the import (56\%) comes from Russia, and the remaining part (27\%) constitutes LNG from Qatar, Nigeria, Egypt, Algeria, USA and Norway) [16]. The unconventional gas resources in Poland, UK, Spain, Holland and Germany can be verified and then produced after the year 2020. 


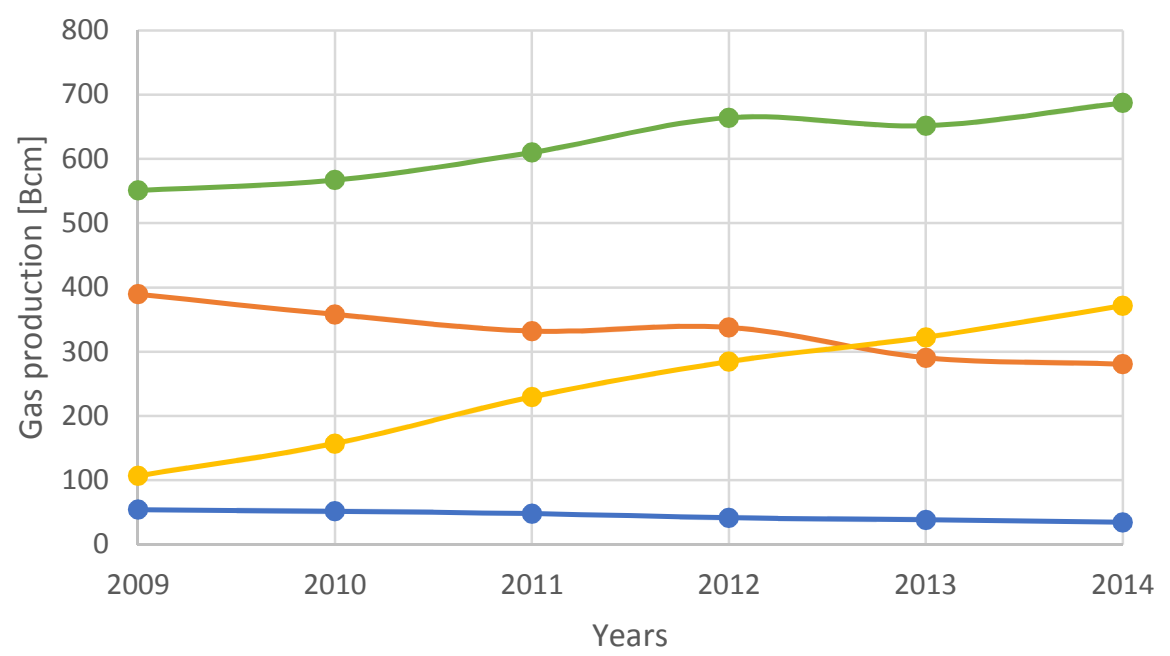

- gas well (conventional) $\quad$ shale gas $\longrightarrow$ CBM $\longrightarrow$ Total gas

Fig. 1. Natural gas production (without gas from oil wells) in the USA in years 2009-2014 (in billion cubic meters $[\mathrm{Bcm}])[12]$

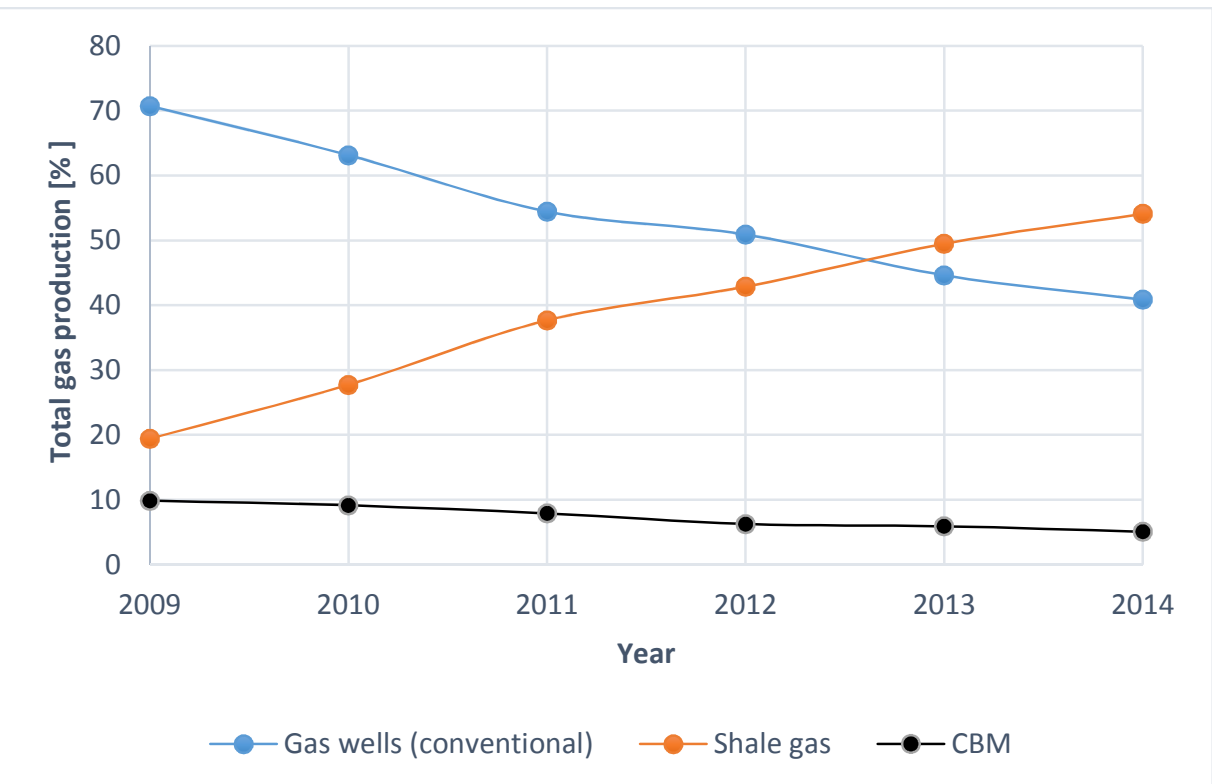

Fig. 2. Percentage of natural gas production from different natural gas reservoirs (without gas from oil wells) in the USA in years 2009-2014 [12] 
The large-scale prospecting works in Poland started in 2010; first seismic profiling, analysis of archival geological data, and finally actual drilling. In the years 2010-2014 over 100 companies were engaged in exploration on 101 concession areas (2011). In reaction to the one-sided and negative opinion about the gas extraction in the ENVI report [20-22], there began own research works on the influence of drilling works and extraction on the natural environment, ordered by the Director General of the Environmental Protection and realized by PGI-NRI, AGH-UST and Gdansk University of Technology.

\section{Polish report on the influence of shale gas prospecting on the natural environment}

Extensive analysis of the environmental impact of unconventional gas prospecting was realized by a scientific consortium of partners: the Polish Geological Institute - National Research Institute, AGH University of Science of Technology and the Gdansk University of Technology [23]. The research areas were localized around wells in which geological prospecting works were performed by seven zones located within the Wejherowo, Elblag, Stara Kiszewa, Lebork, Bytow, Wierzbica and Zwierzyniec concession areas, which were given the name of the closest towns [23, 24]. Five of them were localized in the northern part of the shale rocks occurrence site in the Pomerania province, and two in the SE part in the Lublin province (Fig. 3).

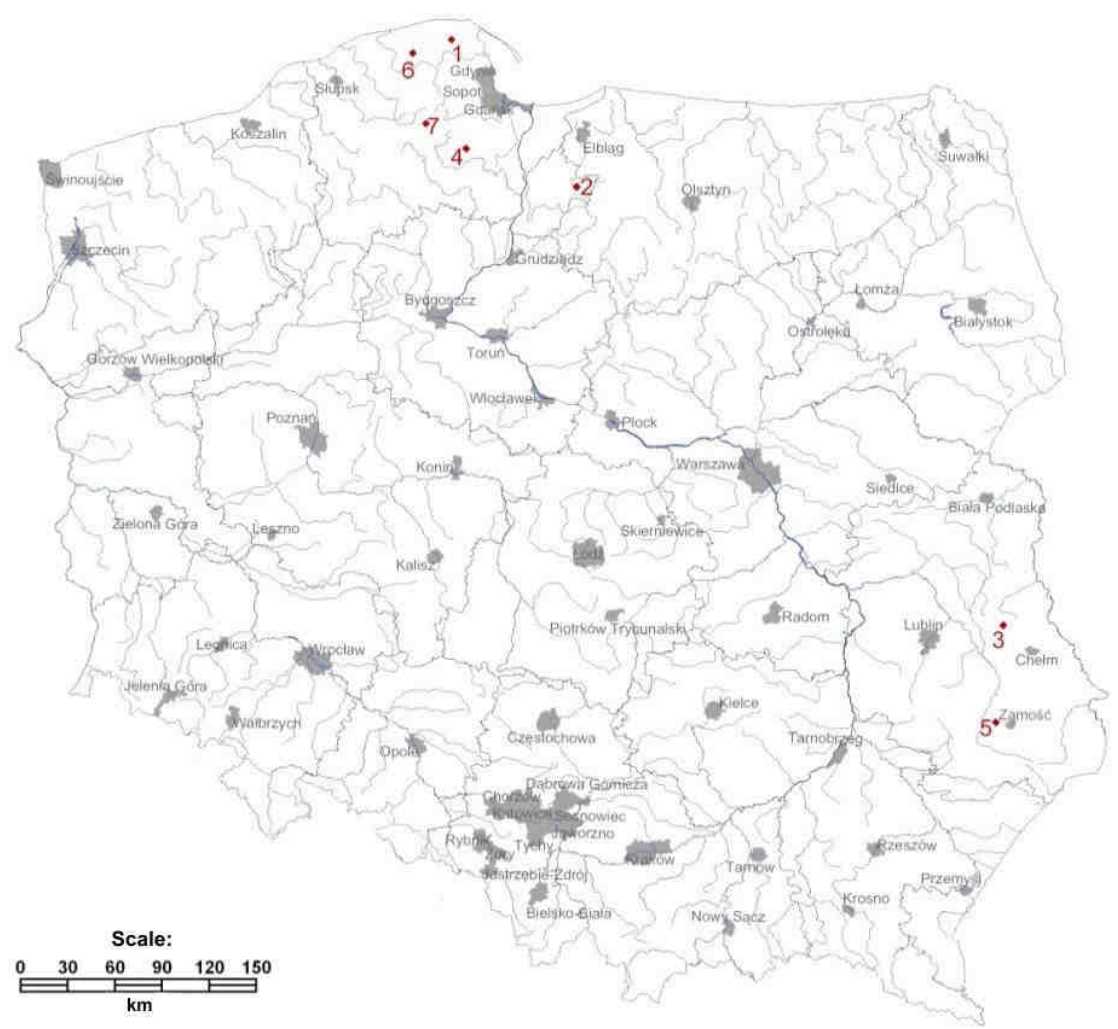

Fig. 3. Test Sites Localization in Poland [23] 
The aim of the research works was establishing the actual impact of natural gas prospecting in shale rocks and also such environmental elements as:

- atmospheric air,

- noise,

- land surface (including its transformation resulting in landscape changes, i.e. vibrations and seismic tremors that may affect the existing infrastructure and stability of morphological elements),

- grounds and soils and their mechanical properties, organic matter content and biophilic substances and potential contamination,

- $\quad$ surface waters and groundwater, taking into account hazards related to excessive depletion of available resources and deterioration of water condition, consequently the contamination with substances from the surface or migrating with technological and reservoir fluids from the geological formations and possible aftermath of such changes to water-dependent ecosystems (Table 1).

Water survey on test sites [23]

Table 1

\begin{tabular}{|c|c|c|c|}
\hline Test site & $\begin{array}{c}\text { Surveyed area - } \\
\text { estimated size } \\
{\left[\mathbf{k m}^{2}\right]}\end{array}$ & $\begin{array}{c}\text { Number } \\
\text { of groundwater } \\
\text { monitoring sites }\end{array}$ & $\begin{array}{c}\text { Number } \\
\text { of surface water } \\
\text { monitoring sites }\end{array}$ \\
\hline Lubocino & 12.5 & 14 & 5 \\
\hline Stare Miasto & 78.5 & 17 & 4 \\
\hline Syczyn & 78.5 & 28 & - \\
\hline Wysin & 28.0 & 16 & 2 \\
\hline Zawada & 78.5 & 15 & 2 \\
\hline Lebien & 39.2 & 9 & 1 \\
\hline Gapowo & 28.0 & 16 & 1 \\
\hline
\end{tabular}

Field works were preceeded by a detailed analysis of geological and hydrogeological conditions of particular research areas, taking into account the degree of confinement of potential reservoir rocks and identification of possible migration pathways of technological and reservoir fluids to usable/fresh groundwater horizons and land surface [18, 25-27]. The full cycle of research has been conducted in following sequences:

1. identification of the local conditions and field studies planning,

2. examination of the baseline status of the environment prior to the commencement of exploration,

3. studies while drilling vertical/directional wells,

4. studies during hydraulic fracture stimulation and gas flow testing,

5. examination of the status of the environment on completion of drill site operations,

6. monitoring of the status of the environment after the completion of downhole operations.

The entire technological process consisted of the preparation of the site on which the rigs were placed, geological works, drilling of vertical and directional wells, stimulation of inflow in targeted formations through hydraulic fracturing, productivity tests with the production of flowback fluids, disassembling of drilling and fracturing equipment, reclamation of terrain [28-31]. The full environmental test cycle was performed only in some of the research areas. However, the condition of particular environmental elements at 
the beginning of the research was determined for all of them as a reference for possible changes during successive stages. Two of them, i.e. Wysin in Pomerania and Zawada in Lublin region represent the actual basic condition. The research was performed before spudding of drilling [23].

\section{Results of tests in Polish research areas}

During successive stages of prospecting, the following measurements and observations were performed: traffic intensity of heavy vehicles, noise emission, dust, volatile compounds and reservoir gases emission [23, 32-34]. Moreover the balance of water and chemical substances used for technological fluids, especially fracturing fluids, was calculated. Analytical samples were collected, and the chemical composition of drilling waste (especially from the target formations), fracturing fluids, flowback fluids and reservoir gases were chemically analyzed. Complete information about the sources and amount of water extracted from technological fluids, the amount of generated waste and its management methods was also gathered [35-37].

After each technological stage (preparation of the well pad, drilling of wells, hydraulic fracturing, reservoir tests, liquidation of the wells and site restoration) marker tests were performed to check the condition of the environment [35]. They were designed for particular research areas given the specific character and the applied prospecting technology. The measurements covered the control of the physicochemical condition of groundwater near the conducted works and analysis of soil gas composition given hydrocarbon content in the area of potential pathways of vertical migration of reservoir fluids, i.e. along the well.

Based on the analysis of geological and hydrogeological conditions, information about the technical jobs and the composition of technological fluids used during geological works in each research area, a long-term environmental monitoring program was worked out. A potential changes can be observed in a long time perspective, no matter whether further works are conducted, or the exploration well is closed and the area recultivated, e.g. in Stare Miasto. Long-term monitoring measurements have been done for three research areas, i.e. Lebien - 2.5 years, Syczyn - 1 year and Stare Miasto - 1.5 year after finishing hydraulic fracturing jobs in exploration wells [23].

Some conclusions about the scope of the environmental impact of drilling works and stimulation of shale beds with hydraulic fracturing can be drawn from the performed measurements and analysis. Perspective shale formations are deposited at great depth and are covered by the sealing caprock, which is important in the context of potential migration of technological or reservoir fluids towards useful aquifers and to the surface owing to low porosity and permeability of the caprock and the lack of conductive/transmissive fault areas [16].

The noise level in the nearest vicinity of the rig can temporarily exceed admissible standards in the dwelling areas for daytime hours [20,32]. These values are usually connected with the operation of generators used for powering the rig and high-pressure pumps during hydraulic fracturing jobs in the shale rocks. Such jobs so far have been only performed during the day. The operation of some machines making use of high-power combustion motors can also generate a temporary increase in exhaust gas concentration in the air, i.e. products of fuel combustion $\left(\mathrm{NO}_{\mathrm{x}}, \mathrm{SO}_{2}\right)$ [24]. The concentration of 
hydrocarbons $\left(\mathrm{C}_{2}-\mathrm{C}_{12}\right)$ and volatile organic compounds in the atmosphere may be also observed.

In some areas of Poland anomalous methane concentration, its heavier homologs and gaseous alkenes $\mathrm{C}_{2}-\mathrm{C}_{4}$, carbon dioxide and nitrogen in soil gas have been observed. The cause of it may be mainly the microbial fermentation of simple organic compounds (as confirmed by carbon isotope analysis of methane in soil gas), and the applied sealing foil (geomembrane) for protecting the rig area against contaminants, which can disable airing of soil. Apart from the results of contemporary microbial processes, higher microconcentrations of alkanes $\mathrm{C}_{2}-\mathrm{C}_{5}$ were observed in the soil gas in the Lublin area, being the evidence of penetration from the reservoir, most probably from coal beds in the Upper Carboniferous strata. The presence of these gases in the near-surface zone may be a result of disturbance of continuity of strata housing natural hydrocarbon accumulations in the Carboniferous beds. In the light of the isotopic analysis, there is no presence of thermogenic gas in the soil, which might come from the Silurian gas-bearing strata.

No increased radon concentrations in soil gas, proving the presence of radionuclides in the reservoir gas and its migration along the casing to the surface, were observed in the areas of the performed prospecting.

The use of groundwater and surface water for the realization of the prospecting works should not create a hazard for useful water resources, provided it was realized in compliance with the local water management policy [5,31]. The water production realized in line with the water permits in all research areas did not significantly affect the condition of groundwater resources and the water level (Table 2). In Table 3 average values of the flowback compositions are given. Hydrocarbon emission concentrations at test sites (b-baseline, d-drilling, f-HF, t- flow test) has been included in Table 4.

Groundwater reserves versus water consumption for fracturing purposes [23]

\begin{tabular}{|c|c|c|c|c|c|c|}
\hline \multirow{3}{*}{ Test site } & \multirow{3}{*}{ 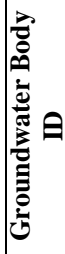 } & $\begin{array}{l}\text { Available } \\
\text { groundwater } \\
\text { resources }\end{array}$ & $\begin{array}{l}\text { Reserve } \\
\text { groundwater } \\
\text { resources }\end{array}$ & \multirow{3}{*}{$\begin{array}{c}\begin{array}{c}\text { Water } \\
\text { withdrawal for } \\
\text { fracturing } \\
\text { purposes }\end{array} \\
{\left[10^{3} \mathrm{~m}^{3}\right]}\end{array}$} & \multirow{3}{*}{$\begin{array}{c}\% \\
\text { of available } \\
\text { groundwater } \\
\text { resources used for } \\
\text { fracturing } \\
\text { purposes }\end{array}$} & \multirow{3}{*}{$\begin{array}{c}\% \\
\text { of reserve } \\
\text { groundwater } \\
\text { resources used for } \\
\text { fracturing } \\
\text { purposes } \\
{[\%]}\end{array}$} \\
\hline & & \multicolumn{2}{|c|}{ (as of 2012) } & & & \\
\hline & & {$\left[10^{3} \mathrm{~m}^{3} /\right.$ year $]$} & {$\left[10^{3} \mathrm{~m}^{3} /\right.$ year $]$} & & & \\
\hline Lubocino & 13 & 110650 & 56161 & 7.967 & 0.007 & 0.014 \\
\hline $\begin{array}{c}\text { Stare } \\
\text { Miasto }\end{array}$ & 19 & 111930 & 103737 & 3.212 & 0.003 & 0.00319 \\
\hline Syczyn & 87 & 79034 & 66476 & 37.849 & 0.05 & 0.057 \\
\hline Wysin & 30 & 119951 & 107375 & none & No fracturing & No fracturing \\
\hline Zawada & 107 & 256792 & 213472 & 1.284 & 0.0005 & 0.0006 \\
\hline Lebien & 11 & 208828 & 190539 & 17.322 & 0.008 & 0.009 \\
\hline Gapowo & 13 & 110650 & 56161 & 25.360 & 0.023 & 0.045 \\
\hline
\end{tabular}


Average values of the flowback compositions [23]

\begin{tabular}{|c|c|c|c|c|c|c|c|c|c|}
\hline \multicolumn{2}{|c|}{ Test site } & \multicolumn{2}{|c|}{ Lubocino } & \multicolumn{3}{|c|}{ Stare Miasto } & \multicolumn{3}{|c|}{ Syczyn } \\
\hline \multicolumn{2}{|c|}{ Aquifer } & \multicolumn{2}{|c|}{ TA } & \multicolumn{3}{|c|}{ TA } & \multicolumn{3}{|c|}{ TA=MCA } \\
\hline \multirow[t]{2}{*}{ Index } & \multirow[t]{2}{*}{ Unit } & Stage I & Stage II & Stage I & Stage II & $\begin{array}{l}\text { Stage } \\
\text { III }\end{array}$ & Stage I & Stage II & Stage III \\
\hline & & \multicolumn{2}{|c|}{ average } & \multicolumn{3}{|c|}{ average } & \multicolumn{3}{|c|}{ average } \\
\hline $\mathrm{pH}$ & - & 7.38 & 7.6 & 7.14 & 6.97 & 7.11 & 7.31 & 7.27 & 7.25 \\
\hline SEC & {$[\mu \mathrm{S} / \mathrm{cm}]$} & 323.7 & 262 & 988 & 802 & 863 & 771 & 830 & 657 \\
\hline $\mathrm{Na}$ & \multirow{13}{*}[\mathrm{mg}/\mathrm{dm}^{3}]{} & 8.73 & 4.28 & 15.94 & 11.1 & 12.96 & 23.57 & 28.62 & 9.72 \\
\hline $\mathrm{K}$ & & 5.92 & 2.63 & 52.12 & 2.2 & 49 & 24.45 & 38.63 & 22.3 \\
\hline $\mathrm{Ca}$ & & 51.75 & 45.00 & 132.54 & 139.8 & 127.8 & 105.85 & 107.35 & 110 \\
\hline $\mathrm{Cl}$ & & 8.82 & 6.88 & 24.62 & 24.62 & 16.87 & 33.77 & 33.22 & 14.2 \\
\hline $\mathrm{Sr}$ & & 0.09 & 0.07 & 0.74 & 0.34 & 0.58 & 0.85 & 0.77 & 1.44 \\
\hline $\mathrm{Br}$ & & $\mathrm{nc}$ & $\mathrm{nc}$ & $\mathrm{nc}$ & $\mathrm{nc}$ & $\mathrm{nc}$ & $\mathrm{nc}$ & $\mathrm{nc}$ & $\mathrm{nc}$ \\
\hline $\mathrm{B}$ & & 0.0175 & 0.0125 & 0.09 & 0.07 & 0.09 & 0.09 & 0.14 & 0.06 \\
\hline $\mathrm{Li}$ & & 0.00071 & 0.00076 & 0.0129 & 0.0074 & 0.0118 & 0.0079 & 0.0065 & 0.0138 \\
\hline $\begin{array}{l}\text { Phenolic } \\
\text { index }\end{array}$ & & 0.01383 & 0.11375 & $\mathrm{nc}$ & $\mathrm{nc}$ & 0.093 & $\mathrm{nc}$ & 0.01828 & 0.1295 \\
\hline Oil index & & 0.0542 & 0.347 & 0.0667 & 0.02563 & 0.0108 & 0.0387 & 0.0306 & $\mathrm{nc}$ \\
\hline $\begin{array}{c}\text { Anionic } \\
\text { detergents }\end{array}$ & & 0.260 & 0.160 & 0.367 & 0.92 & 0.1375 & 0.3655 & 0.3155 & 0.2575 \\
\hline methane & & 0.00060 & 0.00105 & 0.03621 & 0.00143 & 0.00385 & 0.0035 & 0.0014 & 0.0021 \\
\hline BTEX & & $\mathrm{nc}$ & $\mathrm{nc}$ & $\mathrm{nc}$ & $\mathrm{nc}$ & $\mathrm{nc}$ & $\mathrm{nc}$ & $\mathrm{nc}$ & $\mathrm{nc}$ \\
\hline
\end{tabular}

TA - top aquifer, MCA - main commercial aquifer, SEC - specific electrical conductivity, BTEX - benzene, toluene, ethyl benzene, xylene, nc - not calculated (over $50 \%$ below the determination limit), ${ }^{*}$ - low credibility results (further testing required)

Table 4

Hydrocarbon emission concentrations at test sites (b - baseline, $\mathrm{d}$ - drilling, $\mathrm{f}$ - HF, $\mathrm{t}$ - flow test) [23]

\begin{tabular}{|c|c|c|c|c|c|c|c|}
\hline $\begin{array}{l}\text { Indices } \\
\text { Test site }\end{array}$ & $\begin{array}{c}\mathrm{SO}_{2} \\
{\left[\mu \mathrm{g} / \mathrm{m}^{3}\right]}\end{array}$ & $\begin{array}{c}\mathrm{NO}_{\mathrm{x}} \\
{\left[\mu \mathrm{g} / \mathbf{m}^{3}\right]}\end{array}$ & $\begin{array}{c}\text { Methane } \\
{\left[\mu \mathrm{g} / \mathrm{m}^{3}\right]}\end{array}$ & $\begin{array}{c}\mathrm{C}_{2}-\mathrm{C}_{12} \\
\text { hydrocarbons } \\
{\left[\mu \mathrm{g} / \mathrm{m}^{3}\right]} \\
\end{array}$ & $\begin{array}{c}\text { VOC } \\
{\left[\mu \mathrm{g} / \mathrm{m}^{3}\right]}\end{array}$ & $\begin{array}{c}\text { Benzene } \\
{\left[\mu \mathrm{g} / \mathrm{m}^{3}\right]}\end{array}$ & $\begin{array}{c}\text { BTEX } \\
{\left[\mu \mathrm{g} / \mathrm{m}^{3}\right]}\end{array}$ \\
\hline $\begin{array}{l}\text { Value of reference } \\
\text { averaged for } 1 \mathrm{~h}\end{array}$ & 350 & 200 & $\mathrm{nn}$ & 3000 & $\mathrm{nn}$ & 30 & 850 \\
\hline Averaged for 1 year & 20 & 40 & $\mathrm{nn}$ & 1000 & $\mathrm{nn}$ & 5 & 63 \\
\hline $\begin{array}{l}\text { Permitted level } \\
\text { averaged for } 1 \mathrm{~h}\end{array}$ & 350 & nn & $\mathrm{nn}$ & nn & $\mathrm{nn}$ & nn & nn \\
\hline Averaged for 1 year & 20 & 30 & $\mathrm{nn}$ & $\mathrm{nn}$ & $\mathrm{nn}$ & 5 & $\mathrm{nn}$ \\
\hline Lubocino & $169(\mathrm{t})$ & $109(\mathrm{t})$ & $10108(t)$ & $7620(t)$ & $11177(\mathrm{p})$ & 6.0 & $23.5(\mathrm{t})$ \\
\hline Stare Miasto & 815 (f) & $105(\mathrm{f})$ & 1300 (f) & 2900 (f) & $5500(b)$ & $<1$ & 485 (f) \\
\hline Syczyn & 386 (f) & 89 (b) & $1300(b)$ & $2800(b)$ & $15400(\mathrm{~b})$ & $<1$ & $120(\mathrm{f})$ \\
\hline Wysin & $18(\mathrm{~d})$ & $24(\mathrm{~d})$ & $1000(\mathrm{~b})$ & 3920 (d) & $6600(b)$ & $<1$ & $635(d)$ \\
\hline Zawada & $119(\mathrm{f})$ & $62(f)$ & $1400(b)$ & $3500(b)$ & $6500(b)$ & $<1$ & $230(\mathrm{f})$ \\
\hline Gapowo & $133(d)$ & 47 (d) & 3470 (f) & 8544 (f) & 32714 (b) & $3.2(\mathrm{f})$ & 33 (f) \\
\hline
\end{tabular}

VOC - volatile organic carbon, BTEX - benzene, toluene, ethyl benzene, xylene, nn - not normalised

\section{Conclusions}

The research did not show any negative impact of the prospecting works on the chemical condition of groundwater and surface water in the observed time horizon. The 
groundwater was contaminated due to the performed enhancement jobs. However, the quality of useful aquifers and hydrocarbon concentration in the soil gas in the area of drilling should be monitored because reservoir fluids could potentially migrate, e.g. through the cemented annular spaces along the casing (losing its tightness with time).

The obtained results indicate that even small failures or rough operation in the rig area may result in the penetration of some substances from the surface to shallow groundwater. The observed cases do not have an extensive character, and the efficiently operating control system and correct monitoring should help to identify quickly the hazards and undertake suitable measures.

The activity of prospecting companies should not negatively affect soil parameters as far as its agricultural use is concerned, provided correct techniques of soil protection (protections installed around piles of tailings) are applied. Long-term mechanical burdening may increase the compaction of the subsoil and change water and nutrients infiltration conditions, which may temporarily deteriorate the agricultural production in a given area.

The hydrocarbon prospecting and exploration works in shale beds temporarily affect the landscape. After completing the works and restoration of the well pad area, no sign of such activity can be visible. At the stage of hydrocarbon extraction from unconventional deposits, gas or oil mines will continue production for many years, though the technical infrastructure in a majority of cases will occupy a smaller area than the rig area at the initial stage.

Exploration and production of hydrocarbons may have potential and direct short-term negative impact on the environment, including precious natural areas or species subjected to individual protection through such natural elements as air (connected with the dominating direction of the wind) and water (connected with direction of surface run-off) and increased noise level. No indirect impact has been observed in Poland yet, e.g. changes in surface/groundwater levels or flow rates, permanent contamination of air with gases or dust, etc.

Hydraulic fracturing, in particular, in exploration wells does nor induce (in Polish conditions) seismic tremors that would be perceptible on the surface. So far registered tremors have not exceeded the acceptable levels for buildings, according to the Polish standard PN-85/B-02170.

Chemical and toxicological analysis reveal that used drilling mud and drilling cuttings from the exploration wells may create a hazard for living organisms in case they uncontrollably get into the environment. Therefore, it is important to obey the legal regulations and procedures connected with transport, recovery /treatment of waste strictly.

The studies conducted by PGI-AGH-GUT were the first field research works in Europe made in the context of unconventional hydrocarbon prospection and exploration with the borehole method on such a large scale. The results revealed that the exploration works, particularly hydraulic fracturing in horizontal wells did not have any significant impact on the natural environment. Attention should be paid to the fact that the environmental impact of such investments depends on the type of performed works, their intensity, technology and measures implemented for minimizing adverse environmental effects.

The research on the environmental impact of hydrocarbons prospection in unconventional reservoirs conducted in Poland brought about reliable qualitative and quantitative data for further works and risk management models. 
Unlike previous European research projects, which were based only on estimations and data extrapolated from USA and Canada, the current one [35] has been prepared on the basis of real drilling and fracturing done in Poland in years 2011-2014.

\section{Acknowledgements}

This work was done as a result of support of the AGH University of Science and Technology Research Programs no. 11.11.190.555.

\section{References}

[1] Unconventional Gas, Topic Paper \#29: Working Doc. of the NPC Global Oil \& Gas Study, National Petroleum Council Unc. Gas Subgroup of the Technology Task Group of the NPC Committee on Global Oil and Gas. 2007; 18 July. http://www.npc.org/Study_Topic_Papers/29-TTG-Unconventional-gas.

[2] Shonkoff SB, Hays J, Finkel ML. Environmental public health dimensions of shale and tight gas development. Environ Health Perspect. 2014;122:787-795. DOI: 10.1289/ehp.1307866.

[3] MIT. The Future of Natural Gas, An Interdisciplinary MIT Study. Massachusetts Institute of Technology Energy Initiative. June 2011. https://energy.mit.edu/wp-content/uploads/2011/06/MITEI-The-Future-ofNatural-Gas.pdf.

[4] Jenner S, Lamadrid AJ. Shale gas vs. coal: Policy implications from environmental impact comparisons of shale gas, conventional gas, and coal on air, water, and land in the United States. Energy Policy. 2013;53: 442-453. DOI: 10.1016/j.enpol.2012.11.010.

[5] Modern Shale Gas Development in the United States: A Primer. U.S. Department of Energy. Oklahoma City; 2009. http://energy.gov/sites/prod/files/2013/03/f0/ShaleGasPrimer_Online_4-2009.

[6] King GE. Hydraulic Fracturing 101: What Every Representative, Environmentalist, Regulator, Reporter, Investor, University Researcher, Neighbor and Engineer Should Know about Estimating Frac Risk \&Improving Fracturing Performance in Unconventional Gas \& Wells, SPE 152596-MS, SPE Hydraulic Fracturing Technology Conference, 6-8 February, The Woodlands, Texas, USA, 2012. DOI: 10.2118/152596-MS.

[7] Hartmann D, Meylan B. Fracking in der Schweiz aus Sicht des Grund- und Trinkwasserschutzes. Swiss Bull Angew Geol. 2014;19(2):109-113. http://www.saseg.ch/cms/images/pdf/Publikationen/Medien/ SwissBulletin_2-2014-lr.pdf.

[8] Stamford L, Azapagic A. Life cycle environmental impacts of UK shale gas. Appl Energy. 2014;134:506-518. DOI: 10.1016/j.apenergy.2014.08.063.

[9] IEA. Golden Rules for a Golden Age of Gas. World Energy Outlook, Special Report on Unconventional Gas. Report IEA. 2012. http://www.worldenergyoutlook.org/media/weowebsite/2012/goldenrules/ weo2012_goldenrulesreport.pdf.

[10] EPA. Study of the Potential Impacts of Hydraulic Fracturing on Drinking Water Resources. Progress Report EPA 601/R-12/011, December 2012. https://www.epa.gov/sites/production/files/documents/ hf-report20121214.pdf.

[11] EPA. Assessment of the Potential Impacts of Hydraulic Fracturing for Oil and Gas on Drinking Water Resources. External Review Draft EPA/600/R-15/047a, June 2015. https://cfpub.epa.gov/ncea/ hfstudy/recordisplay.cfm?deid=244651.

[12] Babko R, Jaromin-Gleń K, Łagód G, Pawłowska M, Pawłowski A. Effect of drilling mud addition on activated sludge and processes in sequencing batch reactors, Desalin Water Treat. 2016;57(3):1490-1498. DOI: 10.1080/19443994.2015.1033137.

[13] EIA. World Shale Gas Resources: An Initial Assessment of 14 Regions Outside of the United States. Washington D.C.: U.S Department of Energy; April 2011. http://www.documentcloud.org/documents/ 741346-eia-2011-report.html.

[14] EIA. Technically Recoverable Shale Oil and Shale Gas Resources: An Assessment of 137 Shale Formations in 41 Countries Outside the United States. Washington D.C.: U.S Department of Energy; June 2013. https://www.eia.gov/analysis/studies/worldshalegas/archive/2013/pdf/fullreport_2013.pdf.

[15] IEA. World Energy Outlook 2011. Report IEA 2011. https://www.iea.org/publications/freepublications/ publication/WEO2011_WEB.pdf.

[16] Siemek J, Nagy S, Siemek P. Challenges for sustainable development: the case of shale gas exploitation in Poland. Problemy Ekorozwoju - Problems Sust Development. 2013;8(1):91-104. http://ekorozwoj.pol.lublin.pl/no15/j.pdf. 
[17] Pöyry. Macroeconomic Effects of European Shale Gas Production; A report to the International Association of Oil and Gas Producers (OGP), November 2013. http://www.poyry.co.uk/sites/poyry.co.uk/files/ public_report_ogp_v5_0.pdf.

[18] PGI. Assessment of Shale Gas and Shale Oil Resources of the Lower Paleozoic Baltic-Podlasie-Lublin Basin in Poland. First Report. Warszawa: PGI-NRI; March 2012. https://www.pgi.gov.pl/docman-dokumenty-pigpib/docman/aktualnosci-2012/zasoby-gazu/769-raport-en/file.html.

[19] Cotton M, Rattle I, Alstine JV. Shale gas policy in the United Kingdom: An argumentative discourse analysis. Energy Policy. 2014;73:427-438. DOI: 10.1016/j.enpol.2014.05.031.

[20] ENVI. Impacts of shale gas and shale oil extraction on the environment and on human health. Report ENVI EP. 2011. https://europeecologie.eu/IMG/pdf/shale-gas-pe-464-425-final.pdf.

[21] Rahm BG, Bates JT, Bertoia LR, Galford AE, Yoxtheimer DA, Riha SJ. Wastewater management and Marcellus Shale gas development: trends, drivers, and planning implications. J Environ Manage. 2013;120:105-113. DOI: 10.1016/j.jenvman.2013.02.029.

[22] Kargbo DM, Wilhelm RG, Campbell DJ. Natural gas plays in the Marcellus Shale: Challenges and potential opportunities. Environ Sci Technol. 2010;44(15):5679-5684. DOI: 10.1021/es903811p.

[23] Konieczyńska M, Adamczak-Biały T, Brodecki A, Brzezińska A, Janica R, Dziekan-Kamińska E, et al. The Environment and Shale Gas Exploration. Results of Studies on the Soil-Water Environment, Ambient Air, Acoustic, Climate, Process Fluids and Wastes. Warszawa: Directorate General for Environmental Protection; 2015.

http://www.gdos.gov.pl/files/artykuly/38173/The_environment_and_shale_gas_exploration_RESULTS_OF_ STUDIES_ON_THE_SOIL_WATER_ENVIRONMENT_AMBIENT_AIR_ACOUSTIC_CLIMATE_PRO CESS_FLUIDS_AND_WASTES.pdf.

[24] Bogacki M, Macuda $\bar{J}$. The influence of shale rock fracturing equipment operation on atmospheric air quality. Archiv Mining Sci. 2014;59(4):897-912. DOI: 10.2478/amsc-2014-0062.

[25] Vengosh A, Jackson RB, Warner N, Thomas H, Darrah TH, Kondash AA. Critical review of the risks to water resources from unconventional shale gas development and hydraulic fracturing in the United States. Environ Sci Technol. 2014;48(15):8334-8348. DOI: 10.1021/es405118y.

[26] Connor JA, Molofsky LJ, Richardson SD, Bianchi-Mosquera GC. Environmental Issues and Answers Related to Shale Gas Development. SPE Latin American and Caribbean Health, Safety, Environment and Sustainability Conference, 7-8 July, 2015, Bogota, Colombia, DOI: 10.2118/174164-MS.

[27] Nicot JP, Scanlon BR, Reedy RC, Costley RA. Source and fate of hydraulic fracturing water in the Barnett Shale: a historical perspective. Environ Sci Technol. 2014;48(4):2464-2471. DOI: 10.1021/es404050r.

[28] Nicot JP, Scanlon BR. Water use for Shale-gas production in Texas, U.S. Environ Sci Technol. 2012;46(6):3580-3586. DOI: 10.1021/es204602t.

[29] Olsson O, Weichgrebe D, Rosenwinkel K-H. Hydraulic fracturing wastewater in Germany: composition, treatment, concerns. Environ Earth Sci. 2013;70:3895-3906. DOI: 10.1007/s12665-013-2535-4.

[30] Burri P. Unconventionals in Europe: Best practice vs. worst case - the conflict between facts and public perception. Ecol Chem Eng S. 2016;23(3):377-386. DOI: 10.1515/eces-2016-0026.

[31] Vidic RD, Brantley SL, Yoxtheime DA, Abad JD. Impact of shale gas development on regional water quality. Science. 2013;340(6134). DOI: 10.1126/science.1235009.

[32] Wszołek W, Macuda J, Wszołek T. The analysis of the environmental influence of drilling installation. J Acoust Soc Amer. 2000;108(5):2475-2476. DOI: 10.1121/1.4743128.

[33] Warner NR., Christie CA, Jackson RB, Vengosh A. Impacts of shale gas wastewater disposal on water quality in western Pennsylvania. Environ Sci Technol. 2013;47(20):11849-11857. DOI: 10.1021/es402165b.

[34] Reichetseder P. The concept of well integrity in gas production activities. Ecol Chem Eng S. 2016;23(2):205-213. DOI: 10.1515/eces-2016-0013.

[35] Konieczyńska M, Woźnicka M, Antolak O, Janica R, Lichtarski G, Nidental M, et al. Environmental Aspects of Hydraulic Fracturing Treatment Performed on the Łebień LE-2H Well. Final Report. Warszawa: Polish Geological Institute-National Research Institute (PGI-NRI); 2011. http://www.pgi.gov.pl/ docman-tree/kopalnia-wiedzy/gaz-lupkowy/786-the-lebien-report/file.html.

[36] Howarth RW, Santoro R, Ingraffea A. Methane and the greenhouse-gas footprint of natural gas from shale formations. Clim Change. 2011;106:679-690. DOI: 10.1007/s10584-011-0061-5.

[37] Roy AA, Adams PJ, Robinson AL. Air pollutant emissions from the development, production and processing of Marcellus Shale natural gas. J Air Waste Manage Assoc. 2014;64(1):19-37. DOI: 10.1080/10962247.2013.826151. 